\title{
Identification of motives and barriers to physical activity of polish young mothers
}

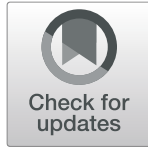

Andrzej Soroka, Agnieszka Godlewska* (D, Elżbieta Krzęcio-Nieczyporuk and Paulina Kozioł

\begin{abstract}
Background: The purpose of the study was to determine the level of physical activity of young mothers living in rural and urban areas and their free time budget. The article also aims to indicate motivating factors and barriers encountered during physical activity.

Methods: A diagnostic survey method, including two survey IPAQ questionnaires - the long version and author's questionnaire, has been applied in the study. A representative sample consisted of 1064 young mothers who gave birth in 2017. Student T test and discriminate function analysis have been used in statistical analysis.

Results: No significant difference appeared between young mothers from rural areas and urban areas in the level of physical activity. At the same time, the authors of the study identified several smaller differences when analyzing particular aspects of physical activity. Young mothers from rural areas more often declared their participation in physical activity to improve their physical condition and reduce pain complaints. On the other hand, young mothers from urban areas emphasized that physical activity helps them to strengthen self-confidence and improve their position in the family. In case of the main barriers to physical activity, both group of respondents pointed to the lack of money and interest in occasional events.

Conclusions: The main conclusion is that more efforts are needed is to strengthen family support and material status of young families. It is also important to eliminate infrastructure barriers, mostly in rural areas and raise awareness on the importance of health education.
\end{abstract}

Keywords: Physical activity, Young mothers, Rural areas, Urban areas, Motives and barriers

\section{Background}

Lifestyle is one of the four main determinants of human health with its most important element that is physical activity. Other important determinants are physical and social environment, genetic factors and organization of medical care. The physical activity is essential for the proper functioning of human body and health $[1,2]$. It also helps to improve human well-being and plays an important role in the treatment of depression and anxiety $[3,4]$. Modern public health studies investigate determinants of physical activity as they may help to fight

\footnotetext{
* Correspondence: godlewskaa@uph.edu.pl

Siedlce University of Natural Sciences and Humanities, Faculty of Medical and Health Sciences, B. Prusa 14 st., 08-110 Siedlce, Poland
}

the pandemic development of non-communicable diseases [5] such as cardiovascular disease, cancer, depression, hypertension, diabetes, and osteoporosis [6-8].

Current trends show that insufficient physical activity has become a global problem, steadily affecting more and more adults and children [9-13] The studies report that people with high socioeconomic status, including profession, income and educational level, very often spent free time on physical activity $[14,15]$. The researchers also point that women are less active than men. This is especially evident in the case of women who lack sport and recreational skills, and have lower socioeconomic and material status [16]. What is more, women's participation in physical activity during free

(c) The Author(s). 2020 Open Access This article is licensed under a Creative Commons Attribution 4.0 International License, which permits use, sharing, adaptation, distribution and reproduction in any medium or format, as long as you give appropriate credit to the original author(s) and the source, provide a link to the Creative Commons licence, and indicate if changes were made. The images or other third party material in this article are included in the article's Creative Commons licence, unless indicated otherwise in a credit line to the material. If material is not included in the article's Creative Commons licence and your intended use is not permitted by statutory regulation or exceeds the permitted use, you will need to obtain permission directly from the copyright holder. To view a copy of this licence, visit http://creativecommons.org/licenses/by/4.0/ The Creative Commons Public Domain Dedication waiver (http://creativecommons.org/publicdomain/zero/1.0/) applies to the data made available in this article, unless otherwise stated in a credit line to the data. 
time regularly declines throughout their life, especially during pregnancy $[17,18]$.

There is evidence to suggest that the onset of parenthood may cause a decline in physical activity of adults $[19,20]$. This is often associated with anxiety, reduced mental well-being and the need to make lifestyle changes $[21,22]$. Both mothers and fathers experience the above mentioned difficulties, however women to a greater extent than men [13].

According to social cognitive theory there is a relationship between environment and behavior [23]. There are studies which report the correlation between environmental factors and physical activity [24]. The physical activity behaviors of adults from rural areas depend on whether their neighbors are also physically active and whether they have access to exercise facilities, [25]. In general, the studies show that rural communities differ significantly from urban ones [26].

\section{Methods}

\section{Study population}

The quota sampling was used as a method for selecting survey participants. The total population of Polish women who gave births to live children in 2017 was 357, 400 [27]. It was divided into two groups: women living in rural areas and those living in towns and cities. While determining the size of representative sample, which eventually consisted of 1064 respondents, the confidence level was set at 0.95 , the estimated size fraction at 0.42 , and the maximum error at 0.03 . The survey was conducted on the basis of respondents' availability, until the limit was reached for each province. Such approach did not create a selection bias. The study was carried out in April 2018 among young mothers who had given birth in 2017. In order to collect study material, the following web portals were used: forum.e-mama.pl, webmama.pl, familie.pl and maluchy.pl.

The study conforms to the code of ethics of the World Medical Association and the standards for research recommendations of the Helsinki Declaration. The protocol was approved by the local university ethics committee at the Siedlce University of Natural Sciences and Humanities. The written consent to participate in the study was obtained from all respondents. All respondents were over 18 years old. To ensure confidentiality, all data were anonymized before analysis. The survey was conducted in the form of telephone inquiries and the data collection procedure was applied. The standard interview with the respondents lasted $10 \mathrm{~min}$.

\section{Data collection and definitions}

A diagnostic survey with two research tools (survey questionnaires) were used in the study. The first tool was IPAQ (International Physical Activity Questionnaire) - long version, developed for measuring four areas of physical activity: profession, housework and outside the home, sports and recreation and everyday movement [28]. This questionnaire is widely used method for determining the level of physical activity [29]. The second questionnaire was the author's survey questionnaire which was used to define leisure time budget of young mothers (Appendix No. 1). It was also applied to determine the hierarchy of motivating factors and barriers that respondents encounter while making attempt to participate in physical activity. The above-mentioned aims refer to a socio-demographic factor that is the place of residence that is rural and urban areas. A five-point Likert scale was used to measure attitudes. The use of questionnaire survey was preceded by two-stage pilot studies which allowed evaluating the content of the questionnaire, examining its reliability, validity, and discriminate power.

The goal of the study is to determine the level of physical activity of young mothers living in rural and urban areas and their free time budget. The study also aims to define the hierarchy of motivating factors and barriers that they encounter during physical activity.

The research hypothesis assumes that young mothers from rural areas have lower level of physical activity and less free time than mothers living in urban areas. Additionally, the main barriers that affect a level of participation in physical activity of young mothers from rural areas are the lack of time, limited financial resources, difficult access to sports and recreation infrastructure, and small support from their families.

\section{Statistical analysis}

The Statistica 13.1 PL software was used in statistical analysis to calculate means and standard deviations. The authors also applied Shapiro-Wilk normality test in order to compare variations, Student $\mathrm{t}$ test to compare the mean values of variables, Chi-square compliance test and discriminant function analysis. They were used to determine which factors of studied phenomena discriminate two naturally emerging groups. The discriminant function analysis was used to calculate the classification function coefficients. Prior to discriminant analysis, the multivariate normality was verified by checking if each variable had a normal distribution. It was assumed that the variancecovariance matrix was homogeneous within groups. Slight deviations that appeared were not valid. It was due to the size of groups which were respectively: 618 in urban and 446 in rural areas. On the other hand, statistically significant were differences of mean values where the probability of uncertainty was less than $p<0.05$.

\section{Results}

The analytical material consisted of 1064 questionnaires (446 collected from rural areas, 618 from urban areas of 
Poland). The mean age of respondents living in rural areas was $25.3 \pm 1.8$, while those from urban areas $29.3 \pm 4.9$. The body mass of respondents from rural areas was $60.7 \pm 8.9 \mathrm{~kg}$ and the body height $165.7 \pm 3.5$ $\mathrm{cm}$. In case of young mothers from urban areas, the body mass was $62.7 \pm 9.6 \mathrm{~kg}$ and the body height $167.3 \pm$ $5.8 \mathrm{~cm}$. The BMI calculation showed that $30.7 \%$ of young mothers from rural areas were underweight, $46.3 \%$ represented normal weight-growth ratio, while $22.9 \%$ were overweight. In case of respondents from urban areas, $25.6 \%$ were underweight, $59.7 \%$ had normal parameters, while $14.6 \%$ were overweight. The rest of analysed parameters are presented in Table 1.

The analysis of obtained results showed no significant differences in the level of physical activity between young mothers living in rural and urban areas. At the same time, the authors reported several smaller differences that appeared in particular areas of physical activity. The respondents from rural areas showed higher level of physical activity $p<0.001$ in the area of professional work, movement and participation in recreation and sport activities. On the other hand, respondents from urban areas showed significantly $(p<0.001)$ higher level of physical activity related to housework (Table 2).

The extremely high value of $\chi^{2}$ test $p<0.001$ shows that there is a strong dependence between the amount of free time and place of residence. Women from rural areas more often than women from urban areas declared their free time budget as more than 5 $\mathrm{h}$ a day, both weekdays and weekends. On the other hand, nearly half of respondents from both surveyed groups declared the limit below $2 \mathrm{~h}$ of free time a day (Table 3).
What is more, the high value of $\chi^{2}$ test indicated a significant difference between the observed values and expected ones. More respondents from rural areas than from urban ones reported that their free time budget was fully sufficient. On the other hand, the same group of respondents more often declared the need to have more free time. Interesting is the fact that there were no respondents from rural areas who suffered from a total lack of free time (Table 4).

Among eleven motives that had influence on young mothers' participation in physical activity, six of them were included in the model of discriminate function. Thus, the following motives were not included in this model: creating healthy lifestyle, improving beauty, improving personal well-being, strengthening immune system and weight loss. The study showed significantly different values of particular motives between two surveyed groups. The highest value of classification function was reached by a motive related to a desire to improve health condition through participation in physical activity,. This was significantly more important $p<0.001$ for respondents from rural than from urban areas. On the other hand, such motives as strengthening self-confidence $(p<0.001)$, strengthening family position $(p<0.001)$ or reducing stress $(p=0.002)$ were significantly more important for women from urban areas than from urban areas (Table 5).

The discriminate analysis and Wilks' Lambda showed significant differences in the values of individual barriers in physical activity faced by young mothers from rural and urban areas. The study reported that the lack of financial resources was the most often declared barrier by all respondents. What is more, the lack of interest in

Table 1 Participants' data

\begin{tabular}{|c|c|c|c|}
\hline \multirow[t]{2}{*}{ Participants' data } & & \multicolumn{2}{|c|}{ Place of residence } \\
\hline & & Urban areas & Rural areas \\
\hline & Age & $29,3 \pm 4,9$ & $25,3 \pm 1,8$ \\
\hline & Body mass & $62,7 \pm 9,6 \mathrm{~kg}$ & $60,7 \pm 8,9 \mathrm{~kg}$ \\
\hline & Body heigh & $167,3 \pm 5,8 \mathrm{~cm}$ & $165,7 \pm 3,5 \mathrm{~cm}$ \\
\hline \multirow[t]{3}{*}{ BMl } & Underweight & $25,6 \%$ & $30,7 \%$ \\
\hline & Normal parametrs & $59,8 \%$ & $46,4 \%$ \\
\hline & Overweight & $14,6 \%$ & $22,9 \%$ \\
\hline \multirow[t]{3}{*}{ Education } & University degree & $79,5 \%$ & $53,9 \%$ \\
\hline & Average education & $17,8 \%$ & $42,2 \%$ \\
\hline & Professional or basic education & $2,7 \%$ & $3,9 \%$ \\
\hline \multirow[t]{3}{*}{ Economic status } & High & $8,2 \%$ & $0 \%$ \\
\hline & Average & $50,1 \%$ & $57,4 \%$ \\
\hline & Low & $41,7 \%$ & $42,6 \%$ \\
\hline
\end{tabular}


Table 2 The level of physical activity in different areas of Polish young mothers living in rural and urban areas (in MET-min./week)

\begin{tabular}{|c|c|c|c|c|c|c|}
\hline \multirow[t]{2}{*}{ Area of physical activity } & \multicolumn{2}{|l|}{ Urban area } & \multicolumn{2}{|l|}{ Rural area } & \multirow{2}{*}{$\begin{array}{l}t \text {-test } \\
\text { value }\end{array}$} & \multirow{2}{*}{$\begin{array}{l}p \\
\text { value }\end{array}$} \\
\hline & $\overline{\bar{x}} \pm S D$ & $\mathrm{n}$ & $\overline{\bar{X}} \pm S D$ & $n$ & & \\
\hline Total activity & $4691.3 \pm 2562.3$ & 618 & $4674.6 \pm 2025.2$ & 446 & 0.240 & 0.810 \\
\hline Professional work & $682.5 \pm 642.1$ & 618 & $1050.6 \pm 623.2$ & 446 & 4.931 & $0.001^{*}$ \\
\hline Movement & $612.5 \pm 554.3$ & 618 & $993.6 \pm 523.2$ & 446 & 4.603 & $0.001^{*}$ \\
\hline Housework & $2548.6 \pm 1765.2$ & 618 & $1386.3 \pm 723.8$ & 446 & 4.101 & $0.001^{*}$ \\
\hline Sport and recreation activities & $847.7 \pm 423.9$ & 618 & $1244.7 \pm 762.2$ & 446 & 6.402 & $0.001^{*}$ \\
\hline
\end{tabular}

sport and recreational offers was the second factor that reached high values in both groups of respondents (Table 6).

\section{Discussion}

There is no evidence for research hypothesis that assumed lower level of physical activity among young mothers from rural areas than those living in urban areas. The level of physical activity in both groups surveyed was similar in contrast to study results conducted in the United States [30, 31]. However, the young Polish mothers choose different types of physical activity. Female respondents from rural areas spent nearly half of their physical activity on housework and work on the farm. This is a common phenomenon which significantly increases daily levels of physical activity of this group of respondents [32].

Around $25 \%$ of total physical activity of both studied populations was related to sports and recreational activities. Dzewaltowski et al. [33] point out to a higher probability that children who are strongly attached to their families will take over the same parenting patterns in adulthood. This especially applies to female children who learn their parents' approach to physical activity, mostly of mothers, and introduce these patterns to their own families in the future [34-37].

Table 3 Free time budget of Polish young mothers on weekdays and weekends with regard to their residence place

\begin{tabular}{lllllll}
\hline Days & $\begin{array}{l}\text { Place of } \\
\text { residence }\end{array}$ & \multicolumn{5}{l}{ Free time budget (\%) } \\
\cline { 3 - 6 } Weekdays & Urban area & 37.42 & 18.13 & 2.41 & 57.96 \\
& Rural area & 19.38 & 14.46 & 8.20 & 42.04 \\
& Total & 56.8 & 32.59 & 10.61 & 100.00 \\
& Pearson chi-square & 71.937 & $p=0.001^{*}$ & \\
Weekends & Urban area & 26.62 & 19.38 & 11.96 & 57.96 \\
& Rural area & 19.38 & 0.00 & 22.66 & 42.04 \\
& Total & 46.00 & 19.38 & 34.62 & 100.00 \\
& Pearson chi-square & 226.598 & $p=0.001^{*}$ & \\
\hline
\end{tabular}

* - difference significant $p<0.05$
A part of research hypothesis concerning leisure time budget was not proven in the case of young mothers from rural areas. The study showed that young women from rural areas, especially on weekdays, had much more leisure time than women living in urban areas. It is worth mentioning that many women from urban areas function in multigenerational families. This helps them to save more free time as all daily duties are divided among a greater number of family members. However, in general the family and housework duties significantly limit women's free time spent on physical activities [38]. It is worth mentioning that mothers of young children tend to meet the needs of their children in the first place, and then their own ones [39]. According to some authors $[40,41]$, this makes them unable to participate in physical activity regularly. The conducted studies show that contemporary Polish young mothers living in rural areas reasonably manage their time. That is why less often they declare the lack of free time than ten years ago [42].

The hypothesis that the lack of financial resources is a barrier for young mothers from rural areas to perform physical activity has been confirmed. The low economic status of young families is often the cause of young mothers' reluctance and the lack of pleasure and motivation to participate in physical activities [43, 44]. On the other hand, the hypothesis that the lack of access to sports and recreation facilities is a reason for non-participation in physical activity has been not proven. It is worth emphasizing

Table 4 Dimension of leisure time of Polish young mothers living in rural and urban areas

\begin{tabular}{llllll}
\hline $\begin{array}{l}\text { Place of } \\
\text { residence }\end{array}$ & \multicolumn{4}{l}{ Leisure time dimension (\%) } & \\
\cline { 2 - 6 } & It is enough & $\begin{array}{l}\text { It could } \\
\text { be more }\end{array}$ & $\begin{array}{l}\text { It is not } \\
\text { enough }\end{array}$ & $\begin{array}{l}\text { No free } \\
\text { time }\end{array}$ & Total \\
\hline Urban area & 6.36 & 13.40 & 26.42 & 11.76 & 57.97 \\
Rural area & 9.74 & 14.46 & 17.84 & 0.00 & 42.04 \\
Total & 16.10 & 27.87 & 44.26 & 11.76 & 100.00 \\
Pearson chi-square & 123.894 & & $p=0.001^{*}$ & \\
\hline
\end{tabular}

* - difference significant $p<0.05$ 
Table 5 Motives which encourage young mothers from urban and rural areas to spend their free time actively

\begin{tabular}{|c|c|c|c|c|c|}
\hline \multirow[t]{3}{*}{ Motive } & \multicolumn{3}{|c|}{ Model of discriminant analysis } & \multicolumn{2}{|l|}{ Classification functions } \\
\hline & \multicolumn{3}{|c|}{$\begin{array}{l}\text { Wilks' Lambda: } 0.437 \\
\mathrm{~F}(10.212)=6.945 p<0.001\end{array}$} & \multicolumn{2}{|l|}{ Place of residence } \\
\hline & Wilks' Lambda & F of introduction & $\mathrm{p}$ level & Urban area $p=0.580$ & Rural area $p=0.420$ \\
\hline Improving health condition & 0.472 & 120.980 & $0.001^{*}$ & 1.498 & 2.803 \\
\hline Improving self-confidence & 0.466 & 72.555 & $0.001^{*}$ & 1.632 & 0.611 \\
\hline Relieving the pain & 0.513 & 41.147 & $0.001^{*}$ & 0.007 & 0.610 \\
\hline Strengthening family position & 0.505 & 30.540 & $0.001^{*}$ & 1.139 & 0.761 \\
\hline Reducing stress & 0.489 & 9.335 & $0.002^{*}$ & 0.177 & 0.101 \\
\hline Body hardening & 0.484 & 2.445 & 0.118 & 0.123 & 0.068 \\
\hline Constant & & & & 7.761 & 9.591 \\
\hline
\end{tabular}

* - difference significant $p<0.05$

Source: Own data on a base of study results

that the previous studies $[25,45]$ indicated that environmental factors and the lack of access to sports and recreation infrastructure exerted a negative impact on the level of participation in physical activity of women from rural areas. The conducted studies showed that young mothers living in rural areas, to a significantly greater extent than women from urban areas, felt the lack of support from their families. Thus, this part of research hypothesis has been proven. The conducted studies confirmed that women from rural areas wanted to strengthen their position in the family and their self-esteem [46, 47]. This also applied, with even greater intensity, to women from urban areas. It can be stated that women, in general, feel unappreciated by their families $[48,49]$. The above mentioned issues seem to be even more important than more traditional problems as weight loss, improving the beauty or creating healthy lifestyle by participating in physical activity. The answers given by the respondents show that the motherhood significantly decreases participation in physical activity, what is confirmed in studies carried by other authors [50-52].

\section{Conclusions}

The study showed that the level of physical activity of young Polish mothers from rural and urban areas was at the same level. However, the differences appeared when choosing the type of physical activity. The priority for young mothers and their families is the growth of their financial resources, thus the raise of their material status. Young mothers, to some extent, should have less daily duties in order to be able to participate in physical activity. This will help them reduce stressful situations and will have a positive effect on restoring a sense of control over their own health and well-being. Young mothers, especially from urban areas, should have more support from their families, especially from their husbands in raising children. This may eliminate stereotypes of young mothers who do not have any free time and strengthen their position in the family and society. The elimination of barriers associated with infrastructure of rural areas such as building bicycle and pedestrian paths, will help young people, including young mothers, spend their free time actively. This social support with the

Table 6 Barriers that hinder young mothers living in rural and urban areas from spending their leisure time actively

\begin{tabular}{|c|c|c|c|c|c|}
\hline \multirow[t]{3}{*}{ Barrier } & \multicolumn{3}{|c|}{ Model of discriminant analysis } & \multicolumn{2}{|l|}{ Classification functions } \\
\hline & \multicolumn{3}{|c|}{$\begin{array}{l}\text { Wilks' Lambda: } 0.507 \\
F(10.212)=6.945 p<0.001\end{array}$} & \multicolumn{2}{|l|}{ Place of residence } \\
\hline & Wilks' Lambda & F of introduction & p level & Urban area $p=0.580$ & Rural area $p=0.420$ \\
\hline No offers of sport and recreational centers & 0.508 & 9.273 & $0.002^{*}$ & 1.443 & 1.724 \\
\hline No family support & 0.501 & 132.017 & $0.001^{*}$ & 0.408 & 1.328 \\
\hline The lack of free time & 0.493 & 17.044 & $0.001^{*}$ & 0.928 & 1.318 \\
\hline No access to sport facilities & 0.521 & 13.581 & $0.001^{*}$ & 1.726 & 1.386 \\
\hline No interests in offers & 0.507 & 8.319 & $0.004^{*}$ & 5.252 & 5.003 \\
\hline No financial resources & 0.486 & 6.919 & $0.008^{*}$ & 7.641 & 7.401 \\
\hline Constant & & & & 21.347 & \\
\hline
\end{tabular}

* - difference significant $p<0.05$

Source: Own data on a base of study results 
support of a spouse and family are factors which should have a positive influence on active behavior of young mothers.

\section{Supplementary information}

Supplementary information accompanies this paper at https://doi.org/10. 1186/s12905-020-01061-y.

\section{Additional file 1}

\section{Abbreviations}

IPAQ: International Physical Activity Questionnaire; MET-min./week: The 1 MET metabolic equivalent corresponds to $\mathrm{O}_{2}$ consumption at rest and equals $3.5 \mathrm{ml} \mathrm{O}_{2} / \mathrm{kg}$ body weight per minute; BMI: Body Mass Index

\section{Acknowledgements}

Not applicable.

\section{Authors' contributions}

AS, AG and EK-N conceptualized the original study. AS and AG data collection, data analysis, manuscript writing/editing, EK-N and PK data collection, data analysis. All authors have read and approved the final manuscript.

\section{Funding}

The results of the research carried out under the research theme No. 7/19/B were financed from the science grant granted by the Ministry of Science and Higher Education The funding source had no role in the design, implementation, data collection, analysis and interpretation of results or in dissemination of findings.

\section{Availability of data and materials}

The data supporting our findings are found at, kept in confidentiality and stored at the corresponding author both in hard and soft copies. If someone wants our data, we are voluntary to share it and the corresponding author should be contacted through the email address on the cover page.

\section{Ethics approval and consent to participate}

The study conforms to the code of ethics of the World Medical Association and the standards for research's recommendation of the 1964 Helsinki Declaration. The protocol was approved by the University Ethics Committee Siedlce University of National Science and Humanities. To ensure confidentiality, all data were anonymised before analysis. Before the respondents started to answer the questions posed in the study, they declared their willingness to participate in the study. Acceptance was provided online. The [informed] written consent to participate in the study was obtained from all respondents.

\section{Consent for publication}

The study participants were informed that finding of the study would published. Identifying images or clinical details of participants that compromise anonymity were not applicable in this manuscript.

\section{Competing interests}

The authors declare that they have no competing interests.

\section{Received: 8 February 2020 Accepted: 30 August 2020}

Published online: 11 September 2020

\section{References}

1. Warburton DER, Nicol CW, Bredin SS. Health benefits of physical activity: the evidence. Can Med Assoc J. 2006. https://doi.org/10.1503/cmaj.051351.

2. Rhodes RE, Bredin SSD, Janssen I, Warburton DER, Bauman A. Physical activity: health impact, prevalence, correlates and interventions. Psychol Health. 2017. https://doi.org/10.1007/s10865-009-9237-0.

3. Gillison FB, Skevington SM, Sato A, Standage M, Evangelidou S. The effects of exercise interventions on quality of life in clinical and healthy populations: a meta-analysis. Soc Sci Med. 2009. https://doi.org/10.1016/j. socscimed.2009.02.028
4. Rebar A, Stanton R, Geard D, Short CE, Duncan M, Vandelanotte C. A metameta-analysis of the effect of physical activity on depression and anxiety in non-clinical adult populations. Health Psychol Rev. 2015. https://doi.org/10. 1080/17437199.2015.1022901.

5. Kohl HW, Craig CL, Lambert EV, Inoue S, Alkandari JR, Leetongin G, Kahlmeier S. The pandemic of physical inactivity: global action for public health. Lancet. 2012;380(9838):294-305.

6. Spence JC, Blanchard CM, Clark M, Plotnikoff R, Storey KE, McCargar L. The role of self-efficacy in explaining gender differences in physical activity among adolescents: a multi-level analysis. J Phys Act Health. 2010. https:// doi.org/10.1123/jpah.7.2.176

7. Ilesanmi-Oyelere BL, Nicole C, Roy NC, Coad J, Kruger MC. Associations between self-reported physical activity, heel ultrasound parameters and bone health measures in post-menopausal women. Int J Environ Res Public Health. 2019. https://doi.org/10.3390/ijerph16173177.

8. Warburton DER, Bredin SSD. Reflections on physical activity and health: what should we recommend ? Can J Cardiol. 2016. https://doi.org/10.1016/j. cjca.2016.01.024

9. Hallal PC, Andersen LB, Bull FC, Guthold R, Haskell W, Ekelund U. Global physical activity levejs: surveillance progress, pitfalls and prospects. Lancet. 2012. https://doi.org/10.1016/S0140-6736(12)60646-1.

10. Lee IM, Shiroma EJ, Lobelo F, Puska P, Blair SN, Katzmarzyk PT. Effect of physical in activity on major non-communicable diseases worldwide: an analysis of burden of disease and life expectancy. Lancet. 2012. https://doi. org/10.1016/S0140-6736(12)61031-9.

11. Saunders J, Hume C, Timperio A, Salmon J. Cross-sectional and longitudinal associations between parenting style and adolescent girls' physical activity. Int J Behav Nutr Phys Act. 2012;9:141.

12. Garcia Bengoechea E, Ruiz Juan F, Bush PL. Delving into the social ecology of leisure-time physical activity among adolescents from south eastern Spain. J Phys Act Health. 2013;10(8):1136-44

13. Mailey EL, McAuley E. Impact of a brief intervention on physical activity and social cognitive determinants among working mothers: a randomized trial. Behav Med. 2014. https://doi.org/10.1007/s10865-013-9492-y.

14. Beenackers MA, Kamphuis CB, Giskes K, Brug J, Kunst AE, Burdorf A, van Lenthe FJ. Socioeconomic inequalities in occupational, leisure-time, and transport related physical activity among European adults: a systematic review. Int J Behav Nutr Phys Act. 2012;9(1):1-23.

15. Hoebel J, Fingerm JD, Kuntz B, Lampert T. Sozioökonomische Unterschiede in der körperlich-sportlichen Aktivität von Erwerbstätigen im mittleren Lebensalter. Bundesgesundheitsbl. 2016;59:188-96.

16. Hull EE, Rofey DL, Robertson RJ, Nagle EF, Otto AD, Aaron AJ. Influence of marriage and parenthood on physical activity: a two-year prospective analysis. J Phys Act Health. 2010. https://doi.org/10.1123/jpah.7.5.577.

17. Bryan S, Walsh P. Physical activity and obesity in Canadian women. BMC Womens Health. 2004;4(Suppl 1):6.

18. Borodulin K, Evenson KR, Herring AH. Physical activity patterns during pregnancy through postpartum. BMC Womens Health. 2009. https://doi.org/ 10.1186/1472-6874-9-32

19. Bellows-Riecken $\mathrm{KH}$, Rhodes RE. A birth of inactivity? A review of physical activity and parenthood. Prev Med. 2008. https://doi.org/10.1016/j.ypmed. 2007.08.003.

20. Rhodes RE, Quinlan A. Predictors of physical activity change in observational designs. Sports Med. 2015. https://doi.org/10.1007/s40279-014-0275-6.

21. Pollman-Schult M. Parenthood and life satisfaction: why don't children make people happy? J Marriage Fam. 2014. https://doi.org/10.1111/jomf.12095.

22. Candelaria JI, Sallis JF, Conway TL, Saelens BE, Frank LD, Slymen DJ. Differences in physical activity among adults in households with and without children. J Phys Act Health. 2012. https://doi.org/10.1123/jpah.9.7. 985.

23. Viswanath K. Perspectives on models of interpersonal health behavior. In: Glanz K, Rimer BK, Viswanath K, editors. Health behavior and health education: Theory, research and practice. 4. San Francisco: Jossey-Bass; 2008. p. 271-85.

24. Nelson NM, Wright A, Lowry RG, Mutrie N. Where is the theoretical basis for understanding and measuring the environment for physical activity? Environ Health Insights. 2008;2:111-6.

25. Frost SS, Goins RT, Hunter RH, Hooker SP, Bryant LL, Kruger J, Pluto D. Effects of the built environment on physical activity of adults living in rural settings. Am J Health Promot. 2010;24:267-83. 
26. Yousefian A, Ziller E, Swartz J, Hartley D. Active living for rural youth: addressing physical inactivity in rural communities. J Public Health Manag Pract. 2009;15:223-31.

27. Poland S. Department of Demographic and Labor Market Studies, basic information on demographic development of Poland until 2018; 2018.

28. Biernat E. International physical activity questionnaire - polish long version. Pol J Sports Med. 2013;29(1):1-5.

29. Fogelholm M, Malmberg J, Suni J, Santtila M, Kyröläinen $H$, Mäntysaari M, Oja P. International physical activity questionnaire: validity against fitness. Med Sci Sports Exerc. 2006;38(4):753-60.

30. Parks SE, Housemann RA, Brownson RC. Differential correlates of physical activity in urban and rural adults of various socioeconomic backgrounds in the United States. J Epidemiol Community Health. 2003. https://doi.org/10. 1136/jech.57.1.29.

31. Bauman AE, Reis RS, Sallis JF, Wells JC, Loos RJ, Martin BW. Correlates of physical activity: whyare some people physically active and others not? Lancet. 2012;380(9838):258-71.

32. Woolf K, Reese CE, Mason MP, Beaird LC, Tudor-Locke C, Vaughan LA. Physical activity is associated with risk factors for chronic disease across adult women's life cycle. J Am Diet Assoc. 2008; doi:10.1016/j.jada.2008.03. 015.

33. Dzewaltowski DA, Ryan GJ, Rosenkranz RR. Parental bonding may moderate the relationship between parent physical actyvity and physical actyvity after school. Psychol Sport Exerc. 2008;9(6):848-54.

34. Madsen KA, McCulloch CE, Crawford PB. Parent modeling: perceptions of parents physical activity predict girls activity throughout adolescence. J Pediatr. 2009. https://doi.org/10.1016/j.jpeds.2008.07.044.

35. del Mar BM, Pich J, Córdova A, Pons A, Tur JA. Association between sedentary behaviour and socioeconomic factors, diet and lifestyle among the Balearic Islands adolescents. BMC Public Health. 2012;12:718.

36. Telama R, Yang X, Viikari J, Valimaki I. Wanne 0, Raitakari O. physical activity from childhood to adulthood: a 21-year tracking study. Am J Prev Med. 2005;28(3):267-73.

37. Machado-Rodrigues AM, Coelho ESMJ, Mota J, Padez C, Martins RA Cumming SP, Riddoch C, Malina RM. Urban-rural contrasts in fitness, physical activity, and sedentary behaviour in adolescents. Health Promot Int. 2014;29(1):118-29.

38. Rhodes RE, Naylor PJ, McKay HA. Pilot study of a family physical activity planning intervention among parents and their children. J Behav Med. 2010. https://doi.org/10.1007/s10865-009-9237-0.

39. Arab-Moghaddam N, Henderson KA, Sheikholeslami R. Women's leisure and constraints to participation: Iranian perspectives. J Leis Res. 2007;39(1):109_ 26

40. Miller YD, Brown WJ. Determinants of active leisure for women with young children - an "ethic of care" prevails. Leis Sci. 2005. https://doi.org/10.1080/ 01490400500227308

41. Lombard C, Deeks A, Ball K, Jolley D, Teede H. Weight, physical activity and dietary behavior change in young mothers: short term results of the HeLPher cluster randomized controlled trial. Nutr J. 2009. https://doi.org/10.1186/ 1475-2891-8-17.

42. Barkin $J \mathrm{~L}$, Wisner $\mathrm{KL}$. The role of maternal self-care in new motherhood. Midwifery. 2013. https://doi.org/10.1016/j.midw.2012.10.001

43. Hesketh KR, Goodfellow L, Ekelund U, McMinn AM, Godfrey KM, Inskip HM, Cooper C, Harvey NC, van Sluijs EM. Activity levels in mothers and their preschool children. Pediatrics. 2014. https://doi.org/10.1542/peds.2013-3153.

44. Lackman J, Smith ML, McNeill EB. Freshman college students' reasons for enrolling in and anticipated benefits from a basic college physical education activity course. Front Public Health. 2015. https://doi.org/10.3389/ fpubh.2015.00162.

45. Eyler AA, Vest JR. Environmental and policy factors related to physical activity in rural white women. Women Health. 2002;36(2):111-21.

46. Pope CJ, Mazmanian D. Breastfeeding and postpartum depression: an overview and methodological recommendations for future research. Depress Res Treat. 2016. https://doi.org/10.1155/2016/4765310.

47. Ankoye R, Acheampong E, Budu-Ainooson A, Obeng El, Akwasi AG. Prevalence of postpartum depression and interventions utilized for its management. Ann General Psychiatry. 2018. https://doi.org/10.1186/s12991018-0188-0.

48. Christopher K. Extensive mothering: employed mothers' constructions of the good mother. Gend Soc. 2012;26:73-96.
49. Rhodes RE, Blanchard CM, Benoit C, Naylor PJ, Levy-Milne R, Warburton DER, Symons DD. Belief-level markers of physical activity among young adult couples: comparisons across couples without children and new parents. Psychol Health. 2014. https://doi.org/10.1080/08870446.2014.929687.

50. Adachi-Mejia AM, Drake KM, MacKenzie TA, Titus-Ernstoff L, Longacre MR, Hendricks KM, Beach ML, Dalton MA. Perceived intrinsic barriers to physical activity among rural mothers. J Women's Health (Larchmt). 2010. https://doi. org/10.1089/jwh.2009.1879.

51. Craig L, Mullan K. Parenthood, gender and work-family time in the United States, Australia, Italy, France, and Denmark. J Marriage Fam. 2010;72:134461.

52. Esteban-Cornejo I, Hallal CP, Mielke IG, Menezes AMB, Goncalves H, Wehrmeister F, Ekelund ULF, Rombaldi AJ. Physical activity throughout adolescence and cognitive performance at 18 years of age. Med Sci Sports Exerc. 2015:47(12):2552-7.

\section{Publisher's Note}

Springer Nature remains neutral with regard to jurisdictional claims in published maps and institutional affiliations.

Ready to submit your research? Choose BMC and benefit from:

- fast, convenient online submission

- thorough peer review by experienced researchers in your field

- rapid publication on acceptance

- support for research data, including large and complex data types

- gold Open Access which fosters wider collaboration and increased citations

- maximum visibility for your research: over $100 \mathrm{M}$ website views per year

At $\mathrm{BMC}$, research is always in progress.

Learn more biomedcentral.com/submissions 